\title{
Validitas Prediktif PAPI-Kostick dan BAUM terhadap Pengendalian Emosi Karyawan
}

\author{
Alice Whita Savira ${ }^{1}, \mathcal{E}$ Rahmat Hidayat ${ }^{2}$ \\ 1,2Fakultas Psikologi Universitas Gadjah Mada
}

\begin{abstract}
The availability of quality human resources was important for the continuity excellence of company and for gaining competitive advantage in company. It could be obtained by operationalizing development or placement as part of HR management practices based on potential review. This led to the use of psychological tests. The accuracy of psychological tests was required in potential review in order to predict future behavior. HR practitioners and psychologists showed appreciation and confidence in psychological tests. However, it had not been fully supported by empirical evidence regarding the accuracy of the tests for selecting employees. The purpose of this study was to figure out the extent both tools in predicting emotion control. The finding from 159 subjects showed that the activity factor PAPI-Kostick and crown of tree predicted the emotion control.
\end{abstract}

Keywords: emotion control; predictive validity

Abstrak. Untuk kesinambungan kinerja perusahaan dan capaian keuntungan kompetitif, diperlukan manajemen SDM potential review. Potential review memerlukan peran alat tes psikologi yang akurat untuk memprediksi perilaku. Apresiasi dan kepercayaan psikolog pada alat tes psikologi belum didukung oleh bukti-bukti empiris (evidance based) mengenai hal tersebut. Tujuan penelitian ini untuk melihat sejauh mana PAPI-Kostick dan BAUM mampu memprediksi pengendalian emosi. Hasil penelitian pada 159 karyawan, menunjukkan faktor aktivitas PAPI-Kostick dan bagian mahkota pada BAUM dapat memprediksi pengendalian emosi. Sehingga efektivitas penggunaan kedua alat tes psikologi tersebut untuk mengases potensi pengendalian emosi karyawan.

Kata kunci: pengendalian emosi; validitas prediktif

Dewasa ini, dalam rangka pencapaian kesinambungan kinerja perusahaan dan pencapaian keuntungan kompetitif, selain berfokus pada peningkatan teknologi dan inovasi, perusahaan juga perlu menjamin ketersediaan Sumber Daya Manusia (SDM) yang baik (Schermerhorn, 2010; Koopmans, Hildebrandt, Bernaards, \& Schaufeli, 2011; Almatrooshi \& Singh,

\footnotetext{
${ }^{1}$ Korespondensi mengenai artikel ini dapat melalui: alice.whita.s@mail.ugm.ac.id,

2r.hidayat@ugm.ac.id
}

2016). Hal ini mengarahkan pada pentingnya manajemen atau pengelolaan SDM yang baik pula (Schermerhorn, 2010; Albrecht, Bakker, Gruman, Macey, \& Saks, 2015). Salah satu bentuk praktik manajemen SDM adalah potential review untuk mengevaluasi kapasitas baik kognitif maupun kepribadian seorang karyawan (Dharmaraj \& Sulaiman, 2015). Evaluasi terhadap kedua hal tersebut akan dijadikan dasar untuk menentukan kebutuhan pengembangan dan kecocokan dengan 
budaya perusahaan dan posisi pekerjaannya.

Potential review mengarahkan peran asesmen psikologi (Furnham, 2008; Furnham \& Jackson, 2011; Kluemper, DeGroot, \& Choi, 2011). Salah satu alat yang digunakan dalam asesmen psikologi adalah tes psikologi (Cohen-Swerdlik, 2009). Beberapa penelitian menunjukkan bukti mengenai apresiasi profesi psikolog terhadap tes psikologi terutama tes kepribadian sebagai bagian yang terintegrasi praktik manajemen SDM khususnya seleksi dan pengembangan karyawan (Hodgkinson, Dale, \& Payne, 1995; Gatewood \& Field, 1998; Johnson \& Kleiner, 2000; Domino \& Domino, 2006; Carless, 2009; Urbina, 2014). Alat tes kepribadian yang cukup populer digunakan oleh profesi psikolog adalah PAPIKostick dan BAUM (Prabowo, Nisa, \& Jadmiko, 2016). Hal ini didukung oleh data survey awal kepada 44 orang praktisi HR dan psikolog dari berbagai daerah di Indonesia.

Apresiasi dan penggunaan alat tes psikologi seharusnya didukung oleh bukti ilmiah (evidence based) mengenai keakuratan alat tes psikologi tersebut dalam memprediksi perilaku tertentu setelah dilakukannya pengetesan atau yang dalam istilah statistik disebut dengan validitas prediktif. Terlebih survey dan berbagai literatur menunjukkan adanya isu alat tes psikologi yang dianggap tua, diimpor dari barat, digunakan tidak sesuai dengan tujuan awal pembuatan tes, proses pengerjaan dan interpretasi lama dan melelahkan, dan banyak publikasi.

Realitanya Cizek, Rosenberg, \& Koons (2008) yang mereviu berbagai tes untuk berbagai tujuan seperti prestasi pendidikan, kemampuan kepribadian, minat karier, seleksi personal, dan lain-lain, menemukan sebanyak $45.2 \%$ dari 283 tes tidak menunjukkan perspektif akurasi (validitas yang jelas). Dari 49 tes kepribadian yang direviu hanya sebanyak $12.2 \%$ yang mencantumkan bukti akurasi memprediksi perilaku masa depan (validitas prediktif) (Cizek, et al., 2008). Bukti penelitian juga menunjukkan bahwa tes kepribadian menunjukkan koefisien validitas yang rendah (Schmidt \& Hunter, 1998; Murphy \& Davidshofer, 2005; Thomas \& Scroggins, 2006; Scroggins, Thomas, Morris, 2008b). Terkait dua alat tes kepribadian yang populer di pakai di Indonesia yaitu PAPI-Kostick dan BAUM, sejauh ini belum ditemukan bukti validitas prediktifnya.

Keterbatasan bukti ilmiah ini menjadi salah satu sebab psikolog praktik tidak mendasarkan praktiknya pada bukti ilmiah (Terpstra \& Limpaphayom, 2012). Hal ini akan mengarahkan pengambilan keputusan dalam hal penggunaan alat tes berdasarkan pengalaman personal, opini personal, tuntutan perusahaan, ataupun popularitasnya bukan berdasarkan bukti akan kegunaannya yang efektif untuk melihat potensi atau menyeleksi karyawan (Briner R. , 2007; Barends, Rousseau, \& Briner, 2014).

Dengan diketahuinya validitas prediktif alat tes psikologi, maka akan memberikan keyakinan bahwa alat tes psikologi tersebut memang efektif digunakan untuk memisahkan karyawan yang potensial atau tidak potensial sesuai dengan kebutuhan perusahaan (Carless, 2009; Truxillo, Bauer, \& Erdogan, 2016). Terlebih sesuai dengan kebutuhan psikolog praktik, primary validity bagi alatalat tes psikologi yang mereka gunakan adalah pada validitas prediktif (Domino \& Domino, 2006).

Validitas prediktif mengukur kemampuan prediktor dalam memprediksi kriteria tertentu di masa depan. Validitas 
prediktif melihat korelasi atau hubungan statistik lainnya antara skor prediktor dan kriteria (Murphy \& Davidshofer, 2005). Prediktor dalam penelitian ini adalah alat tes PAPI-Kostick dan BAUM, sedangkan kriterianya adalah pengendalian emosi. Hal ini didasarkan pada belum adanya bukti akurasi untuk alat tes kepribadian yang populer digunakan dan klaim yang dilakukan oleh psikolog praktik mengenai kegunaan kedua alat tersebut untuk melihat potensi perilaku pengendalian emosi seseorang (Tett, Guterman, Bleier, \& Murphy, 2000; Murphy \& Davidshofer, 2005; Scroggins, Thomas, Morris., 2008a). Pengendalian emosi yang dimaksud adalah pengendalian ataupun manajemen emosi dan ekspresinya selama berinteraksi di tempat kerja untuk memenuhi tuntutan pekerjaan atau norma organisasi (Hoschild, 1983; Grandey 2000; Hartel, Zerbe, \& Ashkanasy, 2005). Perusahaan tidak mengharapkan karyawan bereaksi berlebihan terhadap permasalahan dan memilih reaksi yang tidak berguna dalam menghadapi situasi emosional.

Pengendalian emosi menjadi penting karena setiap hari di tempat kerja, individu berhadapan dengan berbagai situasi kerja baik menyenangkan maupun tidak menyenangkan yang membutuhkan respon emosi yang tepat (Urbina, 2014; Griffith, Connelly, \& Thiel, 2014). Selain karena ulasan di atas, terhadap asosiasi konstruk antara PAPI-Kostick dan BAUM sebagai operasionalisasi kepribadian pada pengendalian emosi. Kepribadian adalah prediktor munculnya pengendalian emosi (Motowildo, Borman, \& Schmit, 1997; Jex \& Britt, 2008). Beberapa orang mungkin memiliki tendensi mengalami emosi lebih sering dibandingkan lainnya. Beberapa orang lainnya mungkin akan mengalami emosi yang sama dengan intensitas berbeda terhadap peristiwa yang terjadi
(Costa \& McCrae, 1992; Whiteside \& Lynam, 2001). Berdasarkan uraian di atas, maka diajukan dugaan awal yaitu PAPIKostick dan BAUM masing-masing memprediksi pengendalian emosi. Tujuan dari penelitian ini untuk melihat sejauh mana PAPI-Kostick dan BAUM mampu memprediksi pengendalian emosi. Hal ini dilakukan dengan proses eksplorasi analitik pada seluruh faktor PAPI-Kostick dan bagian-bagian BAUM.

\section{Metode}

\section{Responden}

Responden yang memenuhi kriteria adalah 159 karyawan tenaga kependidikan level kepala seksi dan staf di lingkungan Fakultas Ekonomika dan Bisnis, Universitas Gadjah Mada, Yogyakarta, yang pernah mengikuti asesmen potential review pada tahun 2015 di Lembaga Pengembangan Kualitas Manusia (LPKM) Fakultas Psikologi Universitas Gadjah Mada, Yogyakara. Tenaga kependidikan tersebut terbagi dalam 9 wilayah kerja.

\section{Instrumen}

Personality and Preference Inventory (PAPI) adalah tes kepribadian non proyektif terdiri dari 7 faktor yang mengidentifikasi 10 kebutuhan (needs) individu dan 10 tekanan (press) individu. PAPI-Kostick ini dibuat untuk mengungkap besaranbesaran trait (elemen dasar dari kepribadian) yang berbeda-beda dalam diri seseorang, untuk kemudian diinterpretasi sebagai struktur dasar dari kepribadian itu sendiri (Alwisol, 2009; Jones, 2011). PAPIKostick terbagi menjadi dua yaitu PAPI-N dan PAPI-I. Data PAPI-Kostick yang diambil adalah data PAPI-I yang ada dalam proses potential review tahun 2015 . Hingga penelitian ini dilakukan, belum 
ada bukti penelitian yang menunjukkan validitas dan reliabiitas alat tes PAPI-I.

Tes BAUM (tes gambar pohon) sama seperti tes proyektif lainnya merepresentasikan struktur kepribadian id-ego-super ego dari pandangan Freud. Id terdiri dari bagian yang tidak terorganisir dari struktur kepribadian yang mengungkap kebutuhan dasar, insting, impuls, dan dorongan. Id diinterpretasi melalui bagian akar. Ego mengungkap hal-hal sadar yang berkaitan dengan tindakan sadar dan terencana dalam memenuhi id. Ego mencakup persepsi, intelektual kognitif, dan fungsi defensif (Castillo, Kacprzyk, \& Pedrycz, 2010). Hal ini diinterpretasi melalui bagian batang. Sedangkan superego mengacu pada kontrol terhadap id dan ego, pengendalikan impuls, yang bertugas untuk menyempurnakan. Superego mencakup fungsi kritik atau melarang dorongan, perasaan, fantasi, maupun tindakan (Castillo et al., 2010). Data BAUM yang diambil adalah data yang ada dalam proses potential review tahun 2015. Hingga penelitian ini dilakukan, belum ada bukti penelitian yang menunjukkan validitas dan reliabiitas alat tes BAUM.

Pengendalian emosi diukur melalui penilaian dari atasan, kolega, dan self report. Penilaian pengendalian emosi disusun dengan referensi skala emotional labor. Cronbach's Alpha skala ini $=0,96$.

\section{Analisis}

Analisis regresi berganda dan diskiriminan digunakan dalam penelitian ini. Analisis regresi berganda digunakan untuk mengukur kekuatan hubungan antara predikor dan kriteria juga menunjukkan arah hubungan antara keduanya. Analisis diskriminan untuk menentukan bobot dari prediktor yang paling baik untuk membedakan karyawan dengan pengendalian emosi baik dan kurang baik.

\section{Hasil}

Tabel 1

Data demografis

\begin{tabular}{llr}
\hline \multicolumn{1}{c}{ Deskripsi } & \multicolumn{1}{c}{ Keterangan } & Jumlah \\
\hline Jumlah Responden & & 159 \\
Jenis Kelamin & Laki-Laki & 125 \\
& Perempuan & 34 \\
Tempat Penelitian & Wisma MM & 47 \\
& S1 & 19 \\
& PPAK & 8 \\
& P2EB & 10 \\
& MSI DOKTOR & 8 \\
& MM JOG & 12 \\
& MM JKT & 41 \\
& MEP & 6 \\
& MAKSI & 8 \\
\hline
\end{tabular}

Tabel 2

Reliabilitas alat ukur

\begin{tabular}{|c|c|c|c|}
\hline $\begin{array}{l}\text { Reliabilitas } \\
\qquad \begin{array}{l}\text { Instrumen } \\
\text { Alat Tes }\end{array}\end{array}$ & $\begin{array}{l}\text { Penilaian Perilaku } \\
\text { Pengendalian Emosi }\end{array}$ & BAUM & PAPI-Kostick \\
\hline Konsistensi internal rekan kerja & $r_{x x^{\prime}}=0,877$ & & \\
\hline Konsistensi internal diri sendiri & $r_{x x^{\prime}}=0,768$ & & \\
\hline Konsistensi internal atasan & $r_{x x^{\prime}}=0,646$ & & \\
\hline Komposit & & & $\mathrm{r}_{\mathrm{xx}}{ }^{\prime}=0,947$ \\
\hline Inter-rater & $r_{x x^{\prime}}=0,069$ & $r_{x x}^{\prime}=0,58$ & \\
\hline
\end{tabular}


Reliabilitas alat ukur penilaian perila$\mathrm{ku}$ pengendalian emosi oleh rekan kerja, diri sendiri, dan atasan masing-masing. Namun demikian, tidak ada inter-korelasi diantara ketiganya (Tabel 2). Hal ini didukung oleh proses eksplorasi melalui analisis faktor yang menunjukkan bahwa masing-masing rater menginterpretasi hal yang berbeda dalam setiap pernyataan aitem. Hasil ini, mengarahkan peneliti untuk menggunakan nilai total dari ketiga rater bukan menggunakan nilai rata-rata (Stemler, 2008). Reliabilitas PAPI-Kostick menunjukkan reliabilitas komposit yang baik. Berkebalikan dengan reliabilitas PAPI-Kostick, pada BAUM menunjukkan reliabilitas inter-rater yang kurang baik (Tabel 2).

Analisis diskriminan yang dilakukan dalam penelitian ini tidak menghasilkan prediktor (baik PAPI-Kostick secara keseluruhan, BAUM secara keseluruhan, faktor-faktor PAPI-Kostick, ataupun bagian dan sub-bagian BAUM) yang mampu membedakan karyawan dengan pengendalian emosi baik dan kurang baik. Namun demikian, koefisien Standardized Canonical Discriminant menunjukkan hal yang selaras dengan hasil pada analisis regresi dimana faktor aktivitas pada PAPIKostick dan mahkota (bentuk, kualitas garis mahkota, dan kontur mahkota) adalah faktor/bagian/sub-sub bagian yang memiliki nilai fungsi yang lebih tinggi dibandingkan faktor/bagian/sub-sub bagian lainnya dari masing-masing alat tes PAPI-Kostick dan BAUM dalam membentuk fungsi diskriminan.

Tabel 3

Uji $\mathrm{F}$ analisis regresi

\begin{tabular}{llll}
\hline \multicolumn{1}{c}{ Model Summary } & $\mathrm{R}^{2}$ & $\mathrm{~F}$ & $\mathrm{p}$ \\
\hline PAPI-Kostick terhadap Pengendalian Emosi & 0.052 & 1.184 & 0.135 \\
BAUM terhadap Pengendalian Emosi & 0.083 & 3.496 & 0.009 \\
\hline
\end{tabular}

Tabel 4

Uji t analisis regresi

\begin{tabular}{lcclcc}
\hline \multicolumn{2}{c}{ PAPI Kostick terhadap Pengendalian Emosi } & \multicolumn{3}{c}{ BAUM terhadap Pengendalian Emosi } \\
\hline \multicolumn{1}{c}{ Faktor } & $\mathrm{B}$ & \multicolumn{1}{c}{$\mathrm{p}$} & \multicolumn{1}{c}{ Bagian } & $\mathrm{B}$ & $\mathrm{p}$ \\
\hline Arah kerja & .177 & .568 & Kesan umum & .193 & .714 \\
Kepemimpinan & -.079 & .782 & Batang & .392 & .336 \\
Aktivitas & -.846 & .040 & Mahkota & .806 & .011 \\
Pergaulan & -.215 & .542 & Dahan & -.295 & .428 \\
Gaya kerja & -.354 & .283 & & & \\
Sifat Temperamen & .268 & .391 & & & \\
Ketaatan & .025 & .955 & & & \\
\hline
\end{tabular}


Tabel 5

Uji korelasi sub bagian BAUM terhadap pengendalian emosi

\begin{tabular}{lcc}
\hline \multicolumn{1}{c}{ Uji Korelasi } & $\mathrm{r}$ & $\mathrm{p}$ \\
\hline Proporsi & -.020 & .400 \\
Lokasi & .037 & .322 \\
Kualitas garis batang & .165 & .019 \\
Kontur batang & .169 & .017 \\
Shading batang & .117 & .071 \\
Bentuk mahkota & .183 & .010 \\
Kualitas garis mahkota & .281 & .000 \\
Kontur mahkota & .211 & .004 \\
Bentuk dahan & -.037 & .323 \\
Kualitas garis dahan & .194 & .007 \\
Kontur dahan & .149 & .031 \\
\hline
\end{tabular}

\section{Diskusi}

Hasil penelitian ini menunjukkan bahwa faktor-faktor pada tes PAPI-Kostick yang digunakan dalam potential review secara bersama-sama tidak memprediksi pengendalian emosi karyawan di masa depan (lihat $\mathrm{R}^{2}$ pada Tabel 3). Namun dalam penelitian ini ada temuan berharga yang dapat ditunjukkan. Temuan pertama adalah walaupun faktor-faktor PAPIKostick secara bersama tidak memprediksi pengendalian emosi, namun secara individu, satu faktor dalam PAPI-Kostick yaitu faktor aktivitas memprediksi pengendalian emosi. Faktor aktivitas pada PAPI-Kostick (tabel 4) terdiri dari dua sub faktor, yaitu peran sibuk (V) dan peran penuh semangat kerja (T). Hasil penelitian ini menunjukkan bahwa semakin nilai peran sibuk $(\mathrm{T})$ dan atau peran penuh semangat $(V)$ rendah, maka semakin baik pengendalian emosi karyawan. Temuan berharga kedua BAUM memprediksi pengendalian emosi (tabel 3). Dari keempat bagian gambar pada BAUM yaitu kesan umum, batang, mahkota, dan dahan, secara individual gambar mahkota dapat memprediksi pengendalian emosi (tabel 4). Bagian lebih rinci dari gambar mahkota adalah bentuk mahkota, kualitas garis mahkota, dan kontur mahkota (tabel 5). Semakin karyawan menunjukkan gambar mahkota yang ada dalam panduan kuantifikasi grafis BAUM, semakin karyawan memiliki pengendalian emosi yang baik.

Tujuan dari penelitian ini tercapai. Tujuan yang dimaksud adalah melihat sejauh mana hubungan prediksi dari alat tes PAPI-Kostick dan BAUM terhadap pengendalian emosi. Hal ini dilakukan dengan proses eksplorasi analitik pada seluruh faktor PAPI-Kostick dan bagianbagian BAUM.

Hasil penelitian ini akan dijabarkan dalam dua konteks yaitu secara konseptual dan empiris. Secara konseptual, asosiasi antara kepribadian yang dioperasionalisasikan pada tes kepribadian PAPIKostick dan BAUM dan pengendalian emosi berkontribusi pada korelasi yang positif diantara keduanya (Murphy \& Davidshofer, 2005).

Salah satu faktor PAPI-Kostick yaitu faktor aktivitas dimana didalamnya mencakup peran sibuk (sub faktor T) dan peran penuh semangat (sub faktor $\mathrm{V}$ ) mampu memprediksi pengendalian emosi seseorang. Semakin rendah nilai sub faktor $\mathrm{T}$ dan atau sub faktor $\mathrm{V}$ maka pengen- 
dalian emosinya semakin baik. Hasil penelitian ini dapat dijelaskan bahwa orang dengan peran sibuk $(\mathrm{T})$, sesuai dengan bunyi aitem-aitem pernyataan pada tes PAPI-Kostick menunjukkan peran terburu-buru dan cepat. Orang dengan peran terlalu terburu-buru dan ingin serba cepat merupakan ciri orang yang impulsif. Selain serba terburu-buru dan serba cepat, orang impulsif juga menunjukkan sedikit pertimbangan, ketidaksabaran, rendah pengendalian diri, kontrol emosi yang buruk, dan ketidakmampuan dalam menahan diri dan bertindak atas dorongan atau impuls (Farmer \& Golden, 2009). Dengan penjelasan ini sangat dimungkinkan jika orang dengan skor tinggi pada sub faktor ini diprediksi memiliki pengendalian emosi yang kurang baik. Disamping itu orang dengan peran penuh semangat $(\mathrm{V})$ sesuai dengan bunyi aitem-aitem pernyataan pada tes PAPI-Kostick menunjukkan peran yang bersemangat, bergairah, dan bertenaga. Orang yang terlalu bersemangat, bergairah, bahkan merasa kelebihan tenaga terhadap sesuatu berarti memiliki perasaan yang kuat terhadap sesuatu atau seseorang yang mengarahkan pada obsesif. Ada salah satu pendapat menunjukkan bahwa orang yang terlalu bergairah sering kali kehilangan alasan dan pengendalian emosinya (Vallerand, et al., 2003). Dengan penjelasan ini juga sangat dimungkinkan jika orang dengan skor tinggi pada sub faktor ini diprediksi memiliki pengendalian emosi yang kurang baik.

BAUM secara keseluruhan yang mampu memprediksi pengendalian emosi dapat dijelaskan karena konstruk alat tes ini, salah satunya berhubungan dengan keadaan dan stabilitas emosi individu (Castillo, et al., 2010). Mahkota yang mampu memprediksi pengendalian emosi dapat dijelaskan secara konseptual dimana mahkota ini merupakan superego. Superego ini merupakan struktur kepribadian terorganisir yang mencakup tujuan spiritual dan hati nurani yang akan mengkritik ataupun melarang dorongan, impuls fantasi, perasaan, dan tindakan sebagai manifestasi dari id dan ego (Alwisol, 2009; Castillo, et al., 2010). Namun demikian, temuan ini menunjukkan indikasi yang berkebalikan dengan teori. Seharusnya gambar-gambar tersebut berkorelasi negatif dengan pengendalian emosi dimana semakin menggambar mahkota sesuai dengan panduan kuantifikasi grafis BAUM, semakin buruk pengendalian emosinya.

Secara empiris, ketidakmampuan alat tes PAPI-Kostick dan BAUM secara keseluruhan dalam memprediksi pengendalian emosi ini bisa disebabkan oleh beberapa dugaan. Dilihat dari sisi data kriteria pengendalian emosi ditemukan beberapa temuan. Pertama, kriteria pengendalian emosi merupakan konstruk laten yang memang sulit untuk didefinisikan secara operasional dan diukur (Anastasi \& Urbina, 2007; Azwar, 2009). Namun demikian kriteria ini harus ada dan sangat penting bagi organisasi karena berbagai kejadian baik yang menyenangkan dan tidak menyenangkan dapat terjadi di tempat kerja dan akan menstimulus reaksi emosi karyawan (Urbina, 2014; Griffith, et al., 2014; Hale \& Astlofi, 2014). Terlebih pengendalian emosi akan berdampak pada pelayanan yang baik, kepuasan kerja, menurunkan stress, meningkatkan kualitas keputusan, yang pada akhirnya berhubungan dengan pencapaian kinerja keseluruhan dan efektivitas organisasi (Grandey, 2000). Kedua, penilaian ini berhubungan dengan persepsi subjektif masing-masing rater dalam menginterpretasi konstruk 
pengendalian emosi yang dimaksud oleh peneliti. Ketiga rater tidak jujur, tidak termotivasi, ataupun bias dalam memberikan penilaian. Penilai menilai rata-rata (central tendency), menilai cenderung baik (leniency), menilai pada tempat yang sama tanpa betul-betul mendasarkan pada perilaku yang dinilai (response set), ataupun dipengaruhi oleh impresi yang tidak berhubungan dengan pengendalian emosi (halo effect) (Haladyna, 1997; Armstrong, 2009). Keempat, rater khususnya atasan menilai terlalu banyak karyawan dimana hal ini menyebabkan kelelahan dan menyebabkan menilai tidak objektif. Kelima, penilai benar-benar tidak tertarik dalam penilaian karena merasa penilaian ini tidak bernilai (lack of interest) (Haladyna, 1997).

Kompleksitas penilaian perilaku pengendalian emosi menyebabkan reliabilitas inter-rater penilaian pengendalian emosi ini sangat lemah. Reliabilitas inter rater yang lemah ini menunjukkan bahwa tidak adanya kesepakatan antara 3 rater dalam menilai pengendalian emosi karyawan yang sama. Rendahnya reliabilitas intar rater pada penilaian pengendalian emosi, mengarahkan peneliti menggunakan nilai total dari atasan, rekan, dan bawahan, bukan menggunakan nilai ratarata (Stemler, 2008). Hal ini dilakukan agar karyawan dapat dinilai adil, luas, dan komprehensif dari berbagai perspektif (Armstrong 2009). Penggunaan nilai total ini memfasilitasi pengetahuan yang terbatas dan perbedaan persepsi dari masing-masing rater tentang perilaku pengendalian emosi yang dilakukan oleh karyawan yang dinilai. Rater boleh saja tidak sepakat pada satu fenomena khusus pengendalian emosi namun justru variasi konteks pengendalian emosi yang dimaksud akan menilai pengendalian emosi karyawan lebih komprehensif.
Dilihat dari data prediktor, yaitu data inter-rater BAUM. Persepsi antar 3 rater mengenai gambar hasil tes subjek dengan panduan kuantifikasi grafis BAUM yang dibuat oleh peneliti berbeda-beda. Misal: tekstur batang tajam. Walaupun sudah ada panduan gambar, tekstur batang yang tajam menurut rater 1 dan rater 2 ataupun rater 3 bisa berbeda. Kedua, panduan kuantifikasi BAUM ini dibuat sangat rinci dan panjang dimana ada 31 gambar yang harus dilihat, hal ini memungkinkan rater mengalami kelelahan dalam proses menginterpretasi gambar BAUM milik testee. Kelelahan ini menyebabkan rater menjadi tidak jeli atau teliti lagi dalam menginterpretasi. Misal: Dahan yang terbuka ujungnya. Gambar yang berbedabeda ukuran, bentuk, dan lain sebagainya harus dilihat secara seksama oleh rater, apakah betul dahannya tertutup atau sebenarnya terbuka namun tertutup oleh daun. Hal perbedaan persepsi dan kondisi fisik rater ini juga menyebabkan reliabilitas inter-rater BAUM rendah (Haladyna, 1997). Hal ini berdampak pada reliabilitas interrater BAUM yang tidak cukup tinggi

Ulasan mengenai berbagai kasus reliabilitas di atas, baik reliabilitas kriteria pengendalian emosi dan prediktor BAUM menjadi sesuatu yang penting dalam penelitian ini karena reliabilitas merupakan faktor esensial dalam mengukur validitas (Faleye, 2015). Rendahnya koefisien validitas prediktif yang disebabkan reliabilitas prediktor/kriterianya disebut dengan efek atenuasi (Azwar, 2009). Selain penjelasan empiris, secara konseptual dapat dijelaskan bahwa, hal struktur kepribadian pada BAUM yang diungkap sangat kompleks dan tujuan awal pembuatan alat tes ini sebenarnya untuk kepentingan klinis (membedakan pasien normal dan schizohprenia) (Inadomi, Tanaka, \& Ohta, 2003; Alwisol, 
2009; Castillo et al., 2010 Kaneda, N, \& Saito et al, 2010). Hal ini memungkinkan bahwa BAUM hanya dapat menjelaskan sedikit variasi pengendalian emosi dan sisanya untuk menjelaskan hal lain. Demikian juga dengan PAPI-Kostick yang mengungkap dan memetakan berbagai macam trait kepribadian (Jones, 2011; Cubiks, 2016). Disamping itu, jika dilihat dari metode analisis data yaitu analisis diskriminan, ada dugaan mengenai penentuan cut-off yang mungkin belum tepat. Hal ini bisa terjadi karena perusahaan belum menentukan cut-off secara tepat.

Hasil penelitian ini memberikan pertimbangan baru pada psikolog karena selama ini potensi-potensi yang berhubungan emosi diklaim oleh psikolog dilihat dari faktor sifat dimana di dalamnya mencakup kebutuhan untuk berubah (sub faktor Z), peran pengendalian emosi (sub faktor E), dan kebutuhan untuk agresif (sub faktor). BAUM khususnya bagian mahkota yang menunjukkan mampu memprediksi pengendalian emosi juga merupakan sebuah temuan baru yang dapat dijadikan fokus interpretasi bagi para psikolog dalam analisis kualitatif psikolog guna efisiensi waktu interpretasi. Arah beta pada nilai B mahkota yang positif $(+)$ dimana hal ini berkebalikan dengan teori, belum dapat diimplementasikan pada praktik di lapangan. Dengan demikian, panduan kuantifikasi grafis BAUM juga belum dapat dijadikan acuan interpretasi di lapangan.

\section{Kesimpulan}

Penelitian ini membuktikan bahwa PAPIKostick memprediksi pengendalian emosi terutama pada faktor aktivitas sub faktor peran sibuk (T) dan peran penuh semangat $(\mathrm{V})$ dan BAUM terutama pada bagian mahkota khususnya bentuk, kualitas garis, dan kontur mahkota.

\section{Saran}

Penelitian ini merupakan penelitian yang pertama dan awal untuk membuktikan validitas PAPI-Kostick dan BAUM terhadap perilaku khususnya pengendalian emosi. Dalam kaitannya dengan evaluasi praktik yang telah ada, penelitian validitas prediktif sebagai primary validity praktisi (Domino \& Domino, 2006), memang perlu segera dimulai untuk membuktikan efektivitas alat-alat tes profesi psikologi untuk memprediksi sebuah perilaku di masa depan. Para psikolog praktik dapat memanfaatkan hasil penelitian ini yaitu faktor aktivitas khususnya sub faktor peran sibuk (T) dan peran penuh semangat (V) untuk melihat potensipotensi seseorang yang berhubungan dengan pengendalian emosinya. Walaupun demikian, peneliti selanjutnya, perlu mulai mengulas secara kuat teori yang dapat menjelaskan hubungan prediktif yang dihasilkan dari aitem-aitem PAPIKostick yang ada dalam faktor aktivitas khususnya sub faktor peran sibuk (T) dan peran penuh semangat $(\mathrm{V})$ dengan pengendalian emosi karyawan. Hal ini dapat dimulai dengan mengukur properti psikometri validitas konstruk yang belum ditemukan dalam penelitian lain. Di sisi lain, temuan yang menunjukkan mahkota BAUM untuk memprediksi pengendalian emosi karyawan, memerlukan kehatihatian psikolog praktik dalam mengimplementasikan hasil ini sebagai fokus interpretasi guna efisiensi waktu interpretasi kualitatif praktik yang selama ini dilakukan. Hal ini dikarenakan reliabilitas interrater BAUM dari panduan kuantifikasi BAUM yang dibuat peneliti masih rendah.

Peneliti selanjutnya diharapkan melakukan kajian yang lebih mendalam 
berkaitan properti psikometri berkaitan dengan validitas konstruk dan reliabilitas BAUM, yang belum ditemukan dalam penelitian lain dan guna mengembangkan penelitian awal ini. Salah satu cara yang dapat digunakan adalah membuat lebih rinci formula kuantifikasi BAUM (misal: hal yang dimaksud tajam dan kasar). Hal ini dilakukan agar reliabilitas formula ini menjadi lebih baik. Temuan dengan indikasi berkebalikan dengan teori, formula kuantifikasi grafis BAUM belum dapat digunakan di lapangan. Selain itu, kompleksitas hubungan antara kepribadian dan pengendalian emosi, dalam asesmen perlu mengkombinasikan penggunaan PAPI-Kostick dan BAUM dengan alat ukur lain. Misalnya wawancara, focus group discussion, ataupun menggunakan alat tes kepribadian lainnya.

Bagi peneliti selanjutnya, disarankan untuk membuat lebih rinci dengan batasan-batasan yang lebih jelas pada aitem-aitem penilaian pengendalian emosi. Peneliti selanjutnya juga perlu memberikan pembekalan yang cukup kepada para rater mengenai operasionalisasi konstruk yang dimaksud dan batasan yang diinginkan untuk dinilai. Hal ini diperlukan untuk meminimalisasi bias pada implementasi pengukuran pengendalian emosi karyawan. Namun demikian, penilaian pengendalian emosi dalam penelitian ini yaitu dengan menggunakan nilai total 3 rater bukan menggunakan nilai rata-rata 3 rater sudah dapat menunjukkan pengetahuan dari berbagai sudut pandang mengenai perilaku karyawan yang dinilai.

Dalam rangka memperkaya temuan dan mempertajam diskusi dalam penelitian ini, kajian eksploratif juga disarankan untuk menganalisis faktor demografis (jenis kelamin, usia, dan jabatan) yang belum ada dalam penelitian ini sebagai mediator kemampuan prediksi PAPI-
Kostick dan BAUM pada pengendalian emosi. Utamanya adalah dengan mempertimbangkan faktor jabatan, mengingat pengendalian emosi secara teoritik lebih banyak diperlukan ketika berinteraksi dengan orang lain dan jabatan menentukan intensitas ataupun pola interaksi seseorang.

\section{Kepustakaan}

Albrecht, S. L., Bakker, A. B., Gruman, J. A., Macey, W. H., \& Saks, A. M. (2015). Employee engagement, human resource management practice and competitive advantage. An integrated approach. Journal of Organizational Effectiveness: People and Performance, 2(1), 7-35. doi: 10.1108/JOEPP-08-20140042.

Almatrooshi, B., \& Singh, S. K. (2016). Determinants of organizational performance: A proposed framework. International Journal of Productivity and Performance Management, 65(6). doi: 10. 1108/IJPPM-02-2016-0038

Alwisol. (2009). Psikologi kepribadian. Edisi revisi. Malang: UMM Press.

Armstrong, M. (2009). Armstrong's handbook of performance management. London: Kogan Page.

Anastasi, A., \& Urbina, S. (2007). Psychological testing $7^{\text {th }}$ edition (edisi Indonesia). Indonesia: PT. Indeks.

Azwar, S. (2009). Reliabilitas dan validitas. Yogyakarta: Pustaka Belajar.

Barends, E., Rousseau, D. M., \& Briner, R. B. (2014). Evidence-based management. The basic principles. Amsterdam: Center for Evidence-Based Management.

Briner, R. (2007). Is HRM evidence-based and does it matter? Brigton: Institute for Employment Studies. 
Castillo, O., Kacprzyk, J., \& Pedrycz, W. (2010). Soft computing for intelligent control and mobile robotics. Verlag Berlin Heidelberg: Springer.

Cubiks. (2016). PAPI. Diakses pada 17 Oktober 2016: di http://www.mile.org/ webinar/presentations/cubiks/PAPI_P ersonality_Tool_Flyer.pdf.

Carless, S. A. (2009). Psychological testing for selection purposes : A guide to evidence-based practice for human resource professionals. The International Journal of Human Resource Management, 2517-2532. doi: 10.1080/ 09585190903363821

Costa, P. J., \& McCrae, R. (1992). Revised NEO Personality Inventory (NEO-PI-R) and NEO Five-Factor (NEO-FFI) professional manual. Odessa: FL: Psychological Assessment Resources.

Dharmaraj, D. A., \& Sulaiman, M. I. (2015). Employee's perception of potential appraisal (a study among managerial cadre employees in public sectors in kerala). Journal of Industrial Engineering and Management Science, 5(4), 155-161. doi: 10.9756/BIJIEMS.8119

Cizek, G. J., Rosenberg, S. L., \& Koons, H. H. (2008). Sources of validity evidence for educational and psychological tests. Educational and Psychological Measurement, 68(3), 397-412. doi: 10.1177/0013164407310130

Cohen-Swerdlik. (2009). Psychology. Psychological testing and assessment: An introduction to test and measurement. $7^{\text {th }}$ Edition. United States: McGraw-Hill. Primis Online.

Domino, G., \& Domino, M. L. (2006). Psychological testing: An introduction 2nd edition. New York: Cambridge University Press.

Faleye, B. A. (2015). Predictive validity of students' entry qualifications into mathematics programme in nigeria's. Journal of Education and Human Development, 209-217. doi: 10.15640/ jehd.v4n4a25

Farmer, R. F., \& Golden, J. A. (2009). The forms and functions of impulsive actions: Implications for behavioral assessment and therapy. International Journal of Behavioral Consultation and Therapy, 12-30. doi: 10.1037/h0100870

Furnham, A. (2008). Personality and intelligence at work. Exploring and explaining individual differences at work. New York: Taylor \& Francis e-Library.

Furnham, A., \& Jackson, C. J. (2011). Practitioner reactions to work-related psychological tests. Journal of Managerial Psychology, 26(7), 549-565. doi: 10.1108/02683941111164472

Gatewood, R., \& Feild, H. S. (1998). Human resource selection ( $4^{\text {th }} \mathrm{ed}$ ). Forth Worth: Dryden Press.

Grandey, A. A. (2000). Emotional regulation in the workplace: A new way to conceptualize emotional labor. Journal of Occupational Health Psychology, 5, 95110. doi: 10.1037//1076-8998.5.1.95

Griffith, J. A., Connelly, S., \& Thiel, C. E. (2014). Emotion regulation and intragroup conflict: When more distracted minds prevail. International Journal of Conflict Management, 25(2), 148-170. doi: 10.1108/IJCMA-04-2012-0036

Haladyna, T. M. (1997). Writing test items to evaluate higher order thinking. Boston, MA: Allyn and Bacon

Hale, C. D., \& Astlofi, D. (2014). Measuring learning and performance: A primer $\left(3^{\text {rd }}\right.$ edition). Florida: Saint Leo University.

Hartel, C. E., Zerbe, W. J., \& Ashkanasy, N. M. (2005). Emotions in organizational behavior. Mahwah, New Jersey: Lawrence Erlbaum Associates. 
Hodgkinson, G. P., Dale, N., \& Payne, R. L. (1995). Knowledge of, and attitudes towards, the demographic time bomb. International Journal of Manpower, 16(8), 59-76.

Hochschild, A. R. (1983). The managed heart: Commercialization human feeling. Los Angeles: University of California Press.

Inadomi, H., Tanaka, G., \& Ohta, Y. (2003). Characteristics of tree drawn by patients with paranoid shizophrenia. Psychiatry and Clinical Neuroscience, 57(4), 347-351. doi: 10.1046/j.1440-1819. 2003.01130.x

Jex, S. M., \& Britt, T. W. (2008). Organizational Psychology. A ScientistPractitioner Approach. Second Edition. New Jersey: John Wiley \& Sons, Inc.

Johnson, D. L., \& Kleiner, B. H. (2000). A comparative view of employment testing. Management Research News, 23(7/8), 99-102.

Jones, S. (2011). Psychological testing. The esential guide to using and surviving the most popular recruitment and career development tests. Great Britain: Harriman House Ltd.

Kaneda, A., N, Y.-F., \& Saito et Al, M. (2010). Characteristics of tree drawing test in chronic shizophrenia. Psychiatry and Clinical Neuroscience, 64(2), 141148. doi: 10.1111/j.1440-1819. 2010. 02071.x.

Kluemper, D. H., DeGroot, T., \& Choi, S. (2011). Emotion management ability: Predicting task performance, citizenship, and deviance. Journal of Management, 39(4), 878-905.

Koopmans, L., Hildebrandt, V., Bernaards, C., \& Schaufeli, W. B. (2011). The conceptual framework of individual work performance. Journal of occupational and environmental medicine, $53,856-866$.

Motowildo, S., Borman, W., \& Schmit, M. (1997). A theory of individual differences in task and contextual performance. Human Performance, 10(2), 71-83.

Murphy, K. R., \& Davidshofer, C. O. (2005). Psychological testing. Principles and applications. Sixth edition. New Jersey: Pearson Prentice Hall.

Prabowo, A., Nisa, C. A., \& Jadmiko, G. T. (2016). Profil kepribadian Tes Wartegg (Studi deskriptif pada seleksi karyawan). Seminar ASEAN 2nd Psychology \& Humanity (pp. 23-27). Malang: Psychology Forum UMM.

Schmidt, F. L., \& Hunter, J. E. (1998). The validity and utility of selection methods in personnel psychology practical and theoretical implications of 85 years of research finding. Psychological Bulletin, 124, 262-274. doi: 10.1037/0033-2909.124.2.262

Schemerhorn, J. R. (2010). Introduction to management. United States: John Wiley \& Sons, Inc.

Scroggins, W. A., Thomas, S. L., \& Morris, J. A. (2008a). Psychological testing in personnel selection, part I: A century of psychological testing. Public Personnel Management, 37. doi: 10.1177/ 009102600803700107

Scroggins, W. A., Thomas, S. L., \& Morris, J. A. (2008b). Psychological testing in personnel selection, part II: The refinement of methods and standards in employee selection. Public Personnel Management, 195-198. doi: 10.1177/ 009 102600803700204

Stemler, S. E. (2008). 3 Best Practices in Interrater Reliability. Tucson, Arizona: Sage Publication. 
Terpstra, D. E., \& Limpaphayom, W. (2012). Using evidence-based human resource practices for global competitiveness. International Journal of Business and Management, 107-113. doi: 10.5535/ijbm.v7n12p107

Tett, R. P., Guterman, H. A., Bleier, A., \& Murphy, P. J. (2000). Development and content validation of a "hyperfdimensional" taxonomy of managerial competence. Human Performance, 13(3), 205-251

Thomas, S. L., \& Scroggins, W. A. (2006). Psychological testing in personnel selection: contemporary issues in cognitive ability and personality testing. Journal of business inquiry: Research, education $\mathcal{E}$ application, 5(1), 28-38.

Truxillo, D. M., Bauer, T. N., \& Erdogan, B. (2016). Psychology and work. Perspectives on industrial and organizational psychology. New York: Taylor \& Francis.

Urbina, S. (2014). Essentials of psychological testing. New Jersey: John Wiley \& Sons, Inc.

Vallerand, R. J., Mageau, G. A., Rattele, C. \&., Blanchard, C., Koestner, R., Gagne, M., et al. (2003). Les passions de $\mathrm{l}^{\prime} \mathrm{A}^{\wedge}$ me: On obsessive and harmonious passion. Journal of Persoanlity and Social Psychology, 85(4), 756-767. doi: 10.1037/ 0022-3514.85.4.756

Whiteside, S., \& Lynam, D. (2001). The five factor model and impulsivity: Using a structural model of personality to understand impulsivity. Personality and Individual Differences, 30(4), 669689. doi: 10.1016/ S0191 - 8869(00)000 64-7 